\title{
Obituary: Judith (Judy) Anne Fournier $(1943-2016)$
}

\author{
JEAN-MARC GAGNON ${ }^{1}$, PATRICIA POCKLINGTON ${ }^{2}$, SHEILA BYERS ${ }^{3}$, VALERIE MACDONALD ${ }^{4}$ \\ AND ANDREW S.Y. MACKIE 5 \\ ${ }^{1}$ Canadian Museum of Nature, P.O. Box 3443, Station D, Ottawa, Ontario K1P 6P4, Canada, ${ }^{2}$ Arenicola Marine Ltd., 7 Bishop \\ Avenue, Wolfville, NS B4P 2L3, Canada, ${ }^{3}$ Beaty Biodiversity Museum, 2212 Main Mall, Vancouver, BC V6T 1Z4, Canada, ${ }^{4}$ Biologica \\ Environmental Services Ltd., 459 John Street, Victoria, BC V8T 5H1, Canada, ${ }^{5}$ Amgueddfa Cymru-National Museum Wales, \\ Cathays Park, Cardiff CF10 3 NP, Wales, UK
}

Judy was born on 19 June 1943 and passed away suddenly from a cardiac arrest, on 1 July 2016, while shopping. She completed her Bachelor in Biology at the University of Waterloo in 1967, and spent her entire working career at the Canadian Museum of Nature (formerly known as the National Museum of Natural Sciences, Canada) in Ottawa, retiring in September 1997 after '30 years 1 month'.

Her early work involved the sorting and identifying marine invertebrates for the Canadian Oceanographic Identification Centre (NMNS/COIC; then called the Canadian Aquatic Identification Centre, CAIC). Through this experience, Judy became very familiar with essentially all marine invertebrates, which quickly led to her major interest in polychaetes. Then, in 1979, she was formally appointed as Invertebrate Zoologist (and then, Assistant Curator and Assistant Collection Manager) in charge of the non-crustacean collections, which included the National Annelid Collection.

Judy's first two publications were on tunicates and barnacles, but her first polychaete paper soon appeared (Fournier \& Levings, 1982), and was quickly followed by eight peer-reviewed taxonomic articles over the next 12 years. Considering that her work was primarily about caring for collections and not so much about research, this was a fine accomplishment. Of those, we can highlight the description of new species, the arenicolid Branchiomaldane labradorensis (Fournier \& Barrie, 1987), scalibregmatid Axiokebuita millsi (Pocklington \& Fournier, 1987), hesionid Microphthalmus coustalini and M. hystrix (Fournier, 1991), and dorvilleid Ophryotrocha spatula (Fournier \& Conlan, 1994), as well as the redescription of Cossura longocirrata (Fournier \& Petersen, 1991).

While Judy's career as a polychaete expert was relatively short, mainly due to her other curatorial responsibilities and the major move of the museum collections in 1996-97, she did leave more than publications. She was happy to collaborate with novices in polychaete taxonomy, helping them produce several papers. As a very good illustrator, she liked to provide her own illustrations to these papers.

For the Canadian authors of this obituary, representing the few remaining polychaete specialists in Canada, Judy was the Annelid person at the Museum when we first got involved in polychaete identification. Judy had an encyclopaedic

Corresponding author:

J.-M. Gagnon

Email: JGagnon@mus-nature.ca knowledge of the polychaete literature and provided access to many obscure and difficult to find papers long before the World Wide Web, and brought about the translation of useful Russian literature. She was a real champion of Pat's work and encouraged her to pursue the idea of documenting the distribution of the polychaete fauna of eastern Canadian waters along both latitudinal and depth gradients. She also found some funding to support the project. This augmented the Museum collections with specimens from the Department of Fisheries and Oceans (DFO) Canada and the various consulting companies who sampled the eastern Arctic, Labrador, the Grand Banks of Newfoundland, the Gulf of St Lawrence, the Scotian Shelf and the Bay of Fundy. It is now an excellent resource for all polychaete taxonomists. Sadly, Pat's project could not be completed as no funding could be found to publish the results.

While at the Royal Ontario Museum, Sheila was invited by Judy to join a benthic collecting cruise organized by the DFO Ocean Ecology, Institute of Ocean Sciences (Patricia Bay, Sidney, BC) in the early 1990s. Benthic samples were collected from the majority of fjords along the $\mathrm{BC}$ coastline with specimens residing at both the Canadian Museum of Nature and the Royal Ontario Museum. Judy thrived on polychaetes almost as much as she loved horses. The in-depth conversations on problematic species were thoughtful and informative; generally followed up with relevant papers that prompted further discussion. She always looked at polychaete taxonomy as an investigative journey that gave her no end of energy and pleasure. Judy's passion was infectious and her support unwavering for those polychaete taxonomists lucky enough to know her.

For Val, Judy was a wonderfully generous woman when it came to sharing polychaete information, and assisting those learning the complex taxonomy of the west coast worms. Following intense discussion at the First International Polychaete Conference in Sydney, Australia, Judy became a great champion of tackling the 'Cosmopolitan Species Disease'; Canada, as other regions of the world, being vulnerable to species misidentifications brought about through the use of out-of-area (e.g. European and South African) taxonomic monographs and keys. She was adamant about the importance of type localities, and checking those localities became a daily part of our identification routine. With the publication of more local atlases, the disease was mostly eradicated ... or so we'd like to believe.

Judy participated in the first four International Polychaete Conferences from 1983 to 1992 establishing many 


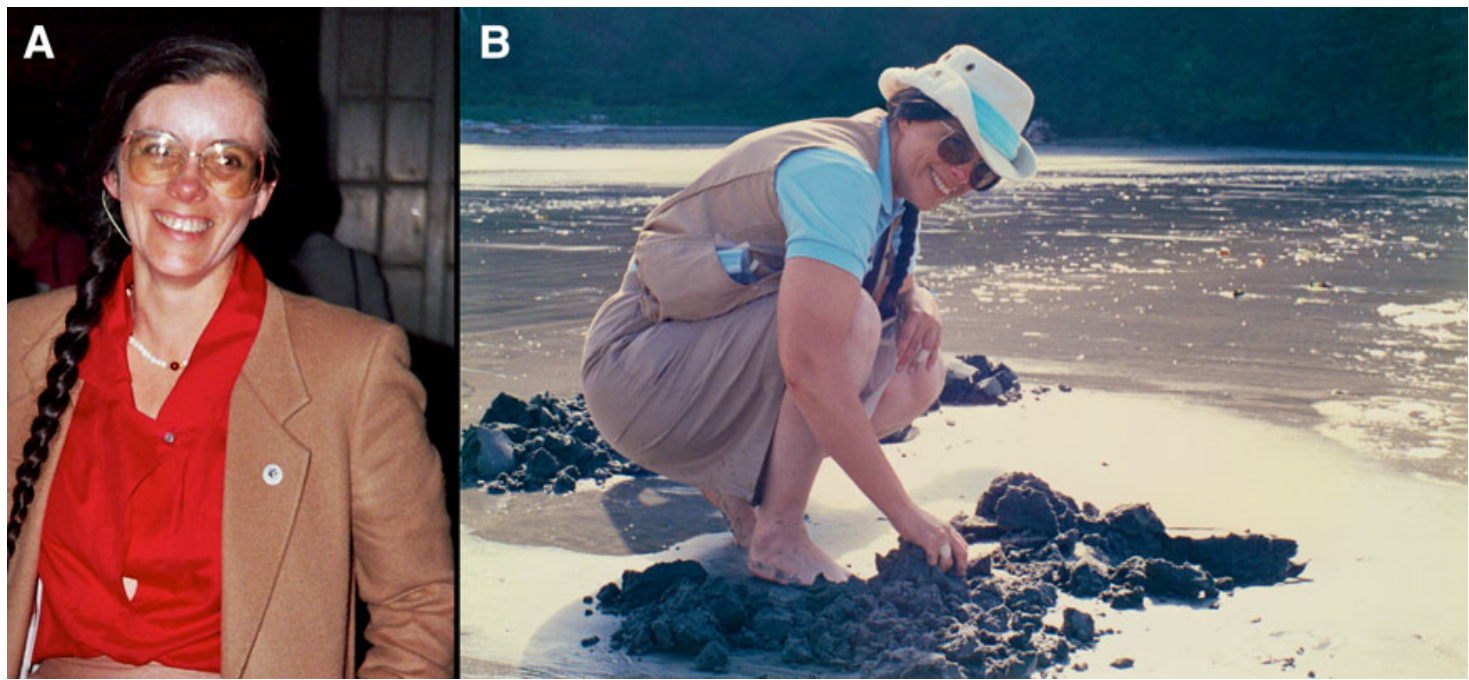

Fig. 1. Judy Fournier: (A) at Second International Polychaete Conference, Copenhagen, Denmark, August 1986; (B) on fieldwork near Bamfield, Vancouver Island, Canada following Third International Polychaete Conference, Long Beach, USA, August 1989. Photographs: Andy Mackie.

long-lasting friendships with collection users and other researchers. Her severe hearing impairment never stopped her from communicating her knowledge and enthusiasm for polychaetes, or her distinctive sense of humour. She will be greatly missed by all who knew her.

For many years, Judy lived at Spiritwood Farm, North Gower, Ottawa and took part in many horse shows in the area. She loved her horse Erin and three cats, and her life on the farm. She is survived by her sisters Doris Crawford and Joan Corriveau. Her parents Sydney and Evelyn Rouse, and brother Sydney, predeceased her.

\section{BIBLIOGRAPHY}

Fournier J.A. and Dewhirst J.T. (1980) Zooarchaeological analysis of barnacle remains from Yuquot, B.C. In Dewhirst J. and Folan W.J. (eds) The Yuquot Project, Volume II. Ottawa: Parks Canada, National Historic Parks and Sites Branch, Minister of Environment, pp. $60-102$

Fournier J.A., Pemberton S.G. and Risk M.J. (1980) Polycylindrichnus: possible Silurian tunicate burrows from southern Ontario. Canadian Journal of Earth Sciences 17, 738-743.

Fournier J.A. and Levings C.D. (1982) Polychaetes recorded near two pulp mills on the coast of northern British Columbia: a preliminary taxonomic and ecological account. Syllogeus 40, 1-90.

Fournier J.A. and Barrie J. (1983) Baffnia hesslei (Annenkova), n. comb. (Polychaeta: Terebellidae) from eastern Canada. Canadian Journal of Zoology 62, 1397-1401.

Fournier J.A. and Pocklington P. (1984) The sublittoral polychaete fauna of the Bras d'Or Lake, Nova Scotia, Canada. In Hutchings P.A. (ed.) Proceedings of the First International Polychaete Conference, Sydney, Australia, 1983. Sydney: The Linnean Society of New South Wales, pp. $254-278$.

Frank P.G., Fournier J.A. and Madill J. (1985) Type specimens of invertebrates (Mollusca and Arthropoda excluded) in the National Museum of Natural Sciences, National Museums of Canada. Syllogeus 60, 1147.
Fournier J.A. and Barrie J. (1987) Revisionary commentary on Branchiomaldane (Polychaeta: Arenicolidae) with description of a new species from Labrador. In Fauchald K. (ed.) Studies on Polychaetes in honor of Marian H. Pettibone. Bulletin of the Biological Society of Washington 7, 97-107.

Pocklington P. and Fournier J.A. (1987) Axiokebuita millsi, new genus, new species (Polychaeta: Scalibregmatidae) from eastern Canada. In Fauchald K. (ed.) Studies on Polychaetes in Honor of Marian H. Pettibone. Bulletin of the Biological Society of Washington 7 , $108-114$.

Fournier J.A. (1991) New species of Microphthalmus (Polychaeta: Hesionidae) from the Pacific Northwest. In Reish D.J. (ed.) Proceedings of the 3 rd International Polychaete Conference, Long Beach, California, 1989. Bulletin of Marine Science 48, 208-213.

Fournier J.A. and Petersen M.E. (1991) Cossura longocirrata: redescription and distribution with notes on reproductive biology and a comparison of described species of Cossura (Polychaeta: Cossuridae). In Petersen M.E. and Kirkegaard J.B. (eds) Systematics, biology and morphology of world Polychaeta. Proceedings of the 2nd International Polychaete Conference, Copenhagen, 1986. Ophelia Suppl. 5, 63-8o.

Fournier J.A. and Conlan K.E. (1994) A new species of Ophryotrocha (Polychaeta: Dorvilleidae) associated with ice-scours in the Canadian Arctic Archipelago. In Dauvin J.-C., Laubier, L. and Reish, D.J. (eds) Actes de la 4ème Conference internationale des Polychétes. Mémoires du Muséum National d'Histoire Naturelle 162, 185-190.

and

Obituary and tributes (2016) http://kellyfhkanata.sharingmemories.ca/ site/JudithAnneFournier.html

\section{Correspondence should be addressed to:} J.-M. Gagnon

Canadian Museum of Nature, P.O. Box 3443, Station D, Ottawa, Ontario $\mathrm{K}_{1} \mathrm{P}$ 6P4, Canada

Email: JGagnon@mus-nature.ca 